\title{
GLIS2 Gene
}

National Cancer Institute

\section{Source}

National Cancer Institute. GLIS2 Gene. NCI Thesaurus. Code C105900.

This gene is involved in transcriptional regulation and signaling pathway modulation. 